\title{
GCU
}

Glasgow Caledonian

University

University for the Common Good

\section{A Welsh European: golf, tourism and the remaking of national imaging}

Harris, John

Published in:

International Journal of Cultural Studies

DOI:

$10.1177 / 1367877916675192$

Publication date:

2018

Document Version

Author accepted manuscript

Link to publication in ResearchOnline

Citation for published version (Harvard):

Harris, J 2018, 'A Welsh European: golf, tourism and the remaking of national imaging', International Journal of Cultural Studies, vol. 21, no. 4, pp. 405-419. https://doi.org/10.1177/1367877916675192

\section{General rights}

Copyright and moral rights for the publications made accessible in the public portal are retained by the authors and/or other copyright owners and it is a condition of accessing publications that users recognise and abide by the legal requirements associated with these rights.

Take down policy

If you believe that this document breaches copyright please view our takedown policy at https://edshare.gcu.ac.uk/id/eprint/5179 for details of how to contact us. 
A Welsh European: Golf, tourism and the remaking of national imaging

(Word count: 7986) 


\title{
A Welsh European: Golf, tourism and the remaking of national imaging
}

\begin{abstract}
The Ryder Cup is a biennial golf match between Europe and the USA that was staged in Wales for the first time in 2010. This article considers the representation of Wales within tourism texts through an analysis of the place of an individual. To date, little scholarship has examined the position of individuals within such discourse and explored the ways in which they can be (re)positioned as representative of a broader (supra)national configuration. In drawing upon the work of the cultural theorist Raymond Williams, it looks at narratives of Wales and the significance of an individual as relates to the interplay of nation, class and place. It argues that Ian Woosnam was centrally important as a 'Welsh European' in providing a physical and symbolic link to an event where no Welshman was a part of Team Europe.
\end{abstract}

Key words: Culture, Raymond Williams, Ryder Cup, Ian Woosnam 


\section{Introduction}

Wales slips into Europe as another political unit, not as a single national identity; as a place with citizens, not a cause with adherents. Wales is an identifiable place, but the Welsh are hardly a people with a distinct, shared, and immutable identity. They should make good Europeans.

(Jones 1992: 357)

At the start of the new millennium the Celtic Manor resort near Newport in south Wales was chosen as the venue for the 2010 Ryder Cup match. Given its claim to be the third biggest sporting event in the world (e.g. Hudson and Hudson 2010; Ryder Cup Wales 2008), then this represented the largest sporting event that Wales could ever conceivably host. The significance of this can be seen in the words of Ryder Cup Wales (2008) who noted that:

The Ryder Cup represents a once-in-a-lifetime opportunity to put Wales on the map. We are an ambitious nation, eager to raise prosperity and to improve the quality of life of the people of Wales. A key element in this process is to increase international awareness of Wales and what we have to offer.

From this it is clear that the event was viewed as something very important in developing the image and reputation of Wales as a nation and as a desirable destination for potential visitors in the competitive golf tourism industry. Having been voted as the 'undiscovered golf destination of the year' as recently as 2003 then Wales was a late-comer to a market 
where its neighbouring nations had been well-established for some years (see Pride 2004). Hosting large-scale events (variously referred to as hallmark events, major events or mega-events) has long been viewed as an important tool in promoting images of a destination and as a means of trying to encourage more tourists to visit (Ritchie 1984). Whilst there continues to be some debate as to the size, appeal and potential impacts of hosting such events (e.g. Harris, 2015; Jones 2001), it is clear that they can play an important role in forming place image and awareness with an increasingly global reach (Hubbert 2015).

The role of sport and sporting events in doing this may be viewed as particularly important for stateless nations such as Wales. The Welsh are often described as the first Britons and different narratives have been used to describe Wales as an internal colony subject to English domination or as an integral part of a colonial power (see Aaron and Williams 2005). Wales is often subsumed under the bigger nation of its neighbour next door as evidenced by the encyclopedia entry for Wales that simply read 'see England'. Wales had never been a unitary kingdom and so the union with England formalized during the Tudor period, made the integration of the two a smoother process than the subsequent union with Scotland at the beginning of the 1700s.

The Celtic Manor resort was the site not only for the first Ryder Cup in Wales but it was also the first time in the history of the event that a new course had been developed especially for the match. Ian Woosnam has a long association with the resort and had an affiliation as a touring professional there in the early 1990s. As Official Ambassador to Ryder Cup Wales, and the first ambassador for Welsh golf, Woosnam became the public face of something deemed as centrally important to (re)creating and (re)imaging the 
nation as a tourist destination and as an important focusing event for Wales to better position itself in the competitive golf tourism market (Pride 2004; Ryder Cup Wales 2010; Visit Wales 2007). What made Woosnam's role even more important was that for many people he may well have been the only recognizable figure from Wales in the sport of golf and thus represented a visible and physical link to an event where no golfer from the host nation would play a part. This paper considers the representations of Woosnam in promoting both the 2010 Ryder Cup and the associated wider development of golf tourism in Wales.

As the US Masters champion in 1991, a member of numerous Ryder Cup teams and captain of the victorious 2006 European team, 'Woosie' is widely regarded as a national hero in Wales and was the recipient of $B B C$ Wales Sports Personality of the year award on three occasions. It would be no exaggeration to say that he almost single-handedly carried the flag of the nation in the international golfing arena for many years. Whilst golf is an individual sport and its leading players may not compete for their respective nations in team competitions as much as rugby players or footballers, athletes almost always represent a place (Bale 2003). Woosnam was part of the two-man team that secured a World Cup win for Wales in 1987 and has stated his pride in representing the country in this event and numerous Dunhill Cup competitions (Woosnam 2002).

Bale (2003: 165) noted that 'what people think places, regions and countries are like is what is important in the way they form judgments of such places'. Here, in the world of international sport, athletes may become visible symbols of a particular place (see Salazar-Sutil 2008). There has been remarkably little consideration given to the role of individuals in relation to tourism and more specifically sport tourism save perhaps for 
work that focuses on heritage and the place of historical figures (Edensor 2002). The strong association between sport and place as identified in the research of scholars such as Bale (2003), and the undoubted importance of sport as a means of national representation (Johnes 2005; Smith and Porter 2004), suggests that it offers particularly fertile ground for the examination of the ways in which the nation is (re)presented in texts aimed at increasing tourism to a host destination through staging a major international event.

An additional layer comes to the fore in the biggest team event in golf, where the players on one team represent more than their respective nations and come together to play for a broader collective (Europe). The Ryder Cup hereby offers a rather unique site to explore the role of an individual, the nation, and the various modes of representation within associated tourism discourse where the one team represents a supranational collective. Before moving on to outline the theoretical underpinning of this work the next section offers a short overview of the Ryder Cup to provide some context for the analysis of this particular case. This is followed by a brief discussion of national identities in relation to tourism and sport in Wales.

\section{The Ryder Cup, Golf Tourism and the Nation}

The Ryder Cup first took place in 1927 although an unofficial match had taken place a year prior to that (Concannon 2004). The trophy was named after the English seed merchant Samuel Ryder, a keen golfer who wanted to see an international competition between the best golfers from Great Britain and the USA. The USA dominated the competition where they won nineteen of the first twenty-two matches. The cup was 
contested every two years with the event alternating between venues in the USA and in England up until 1973 when Scotland were the hosts for the first Great Britain \& Ireland team.

During the 1960s and 1970s such was the USA's dominance of the competition that some expressed concern that the Ryder Cup would cease to exist as it was no longer perceived to be a fair and equal competition. Stafford (2006) describes the decision in 1979 to expand the Great Britain \& Ireland team to include players from elsewhere in Europe as something that 'saved a festival of golf that was in grave danger of petering out' (18) and the event has now developed to become an important occasion on the golfing calendar.

Seve Ballesteros from Spain, a key figure in these early European successes and perhaps the creation of a European team itself, was rewarded for his part in the resurgence of the event when Spain hosted the 1997 Ryder Cup with Ballesteros as Captain. The captaincy is generally given as a reward to someone who has made a significant contribution to the event as a player although this process has not been without its controversies over the years. Ireland staged the Ryder Cup for the first time in 2006, Wales hosted it in 2010 and Scotland provided the location for the event in 2014. The next Ryder Cup to be staged in Europe will take place in France and in 2022 Italy will be the hosts, so in some ways it could be suggested that we are witnessing a developing and emerging Europeanisation of the Ryder Cup. Of course, as Paasi (2001) has noted in a much broader discussion of Europe and European identities, just what we mean and understand by Europe is varied and subject to multiple interpretations. 
The Ryder Cup has evolved into 'one of the great sporting occasions of the modern era' (Concannon 2004: xi), and Stafford (2006: 17) suggests that it 'has become the biggest event in golf, bar none' although others would argue that the four individual majors (The Open, US Open, Masters and USPGA) are more prestigious. Both of the texts referred to above were written for a popular market and there has been limited academic work on the Ryder Cup.

\section{Tourism, Sport and National Identities: The case of Wales}

The importance of both tourism and sport to the (re)presentation of national identities has been looked at by scholars across the world (e.g. Frew and White 2011; Smith and Porter 2004). Edensor's (2002) broader work on popular culture includes numerous references to both tourism and sport in outlining the ways in which national identities are created, imagined and performed. Pitchford (1995) has outlined the role of ethnic tourism in national movements where many of the tourist attractions in Wales such as its castles and industrial museums tell 'a compelling story of Welsh conquest and industrial underdevelopment' (Pitchford, 1995: 50). Morgan and Pritchard's work is important in helping to unpack some of the complexities shaping the promotion of Wales both domestically (in a UK context) and in international markets, highlighting some of the main challenges faced in developing Wales as a brand (Morgan and Pritchard 2005; Pritchard and Morgan 1996, 2001).

Other scholars who have focused their attention to related aspects of tourism in Wales include Saxena and Ilbery's (2008) study of integrated rural tourism, Clifton's (2011) research on place and branding, the work of Jones (2001) on the economic 
impacts of hosting a major sporting event, and Chaney's (2015) analysis of the place of tourism in political parties manifesto discourse. This is by no means an exhaustive list but is included here as an indication of some of the most important work shaping the area that forms the focus of this particular paper. Chaney (2015) highlights the economic role of tourism in Wales, and the increasing importance of sport tourism as part of the rhetoric of nation building in the political discourse.

Sport tourism has also developed markedly as an academic subject in the past twenty years (Gibson 1998; Weed 2009). Sport tourism, particularly through the staging of major international events, has been increasingly used by politicians and a variety of other stakeholders to promote national identity (Rahman and Lockwood 2011), and sport has long been recognized for the important role it plays as a means of national representation in Wales (Johnes 2005). The study of golf tourism has developed markedly in recent years (see Hudson and Hudson 2010) and includes contributions from scholars across a range of disciplinary backgrounds. The scholarly writing on golf tourism has focused primarily on two areas encompassing the behaviour and travel preferences of golf tourists (e.g. Gibson and Pennington-Gray 2005; Hutchinson et al. 2009; Kim et al. 2008; Petrick 2002), and the impacts of golf tourism (e.g. Briassoulis 2007; Gelan 2003; Lim and Patterson 2008). Little has been written to date on golf tourism and image (re)creation from a socio-cultural perspective, with limited consideration of the sport and its biggest international events as a means of (supra)national representation.

All of the above also needs to be located within and around some recognition of the increased commercialization and commodification of elite sport. Mark McCormack's 
promotion of golfer Arnold Palmer in the early 1960s led the way here. McCormack was one of the first to recognize the commercial power of sporting celebrity and founded the International Management Group (IMG) becoming arguably the most powerful man in sport for a time. Ian Woosnam would sign with this agency in 1984 and enjoyed a long and successful relationship with IMG. Woosnam is, to the best of my knowledge, the only Welshman to have featured on the cover of the prestigious Sports Illustrated magazine in the USA. He was the first Welshman to appear in a European Ryder Cup team and the first (and to date only) Welshman to captain Team Europe.

The Ryder Cup offers an interesting site to further explore tourism discourse where golfers from one continent compete as part of Team Europe. The next section will outline the theoretical framework underpinning this and considers the work of Raymond Williams as a lens through which to look at the case study of the 2010 Ryder Cup.

\section{Theoretical framework}

To examine the role of Ian Woosnam in texts produced by organisations such as Visit Wales and Ryder Cup Wales offers an important site to consider the ways in which an individual comes to represent a nation. Extracts from Woosnam's (2002) autobiography are also juxtaposed to this to further explore the ways in which national identities are (re)presented and understood. What is presented is an interpretation of discourse and is not merely a reproduction of the text. The aim here is to focus on (re)presentations of the nation rather than search for some unobtainable truth. This aligns itself with a particular form of analysis, which frequently takes an anti-realist posture, and is not restricted to conclusions about discourse itself (Silverman 2001). No discourse is a complete entity 
and so it is perhaps best viewed as an articulatory practice that constitutes and organizes social relations (Laclau and Mouffe 1985).

This work draws upon the writing of Raymond Williams as a means of framing the study. Turner $(1990,52)$ suggests that the influence of Williams 'has arguably been more profound than any other' within Cultural Studies, whilst McGuigan $(2014, \mathrm{xv})$ refers to him as 'the greatest cultural theorist of modern Britain'. Although known for academic works such as Culture and Society (Williams 1958), The Long Revolution (Williams 1961), and Marxism and Literature (Williams 1977), he was also a prolific writer of other genres and his works of fiction (many of which were partly autobiographical) were set within the Black Mountains (e.g. Williams 1960, 1964). Williams clearly loved that area and his biographers have noted that he considered himself to be more of a writer than a member of the professoriate (see Inglis 1995; Smith 2008) and that it was through his works of fiction that he began to explore the meaning of his native land.

His Welsh identity has at times been overlooked or indeed misrepresented and misunderstood by some clumsy generalizations that fail to engage with the complexities of national identities in a particular locale. That is not to say though that this aspect has been totally ignored for the work of Welsh scholars Dai Smith (2008) and Daniel Williams (2003) have been particularly important in emphasizing the place of Williams's local and national importance. Smith's (2008) biography of Williams, which included access to private papers, offers an insightful analysis of his formative years growing up in Pandy. Daniel Williams (2003) has brought together most of Raymond Williams's 
important writing on Wales together and shows how a more conscious engagement with Wales and wider Welsh issues informed his work in the 1970s and beyond.

It was as a founding figure in the development of Cultural Studies that Williams is perhaps best recognized in academic circles. His work transcended traditional boundaries and appeared across the social sciences (see Williams 1976). Edensor (2002) highlighted that despite the rise of Cultural Studies, the ways in which the nation is experienced and understood through aspects of popular culture needs further study. Whannel $(2008,15)$ notes that as Cultural Studies emerged as an academic subject in Britain during the 1970s 'few writers regarded sport as having any significant importance in the wider scheme of things'. As sports have become increasingly commercialized and commodified, a sociocultural approach can help us better understand the meaning of sport across a range of social milieu and would also seem to represent a useful lens for further exploring the cultural aspects of tourism.

Williams did not sound distinctly Welsh, and Smith (2008) notes how some colleagues expressed surprise when first finding out that Williams was from Wales. His university days and adult working life were spent in England and much of his published work focused on English literature and culture. His self-definition as a 'Welsh European' evidenced a greater engagement with aspects of Welsh culture and the analysis of the meaning of nation and national identities (Williams, 1983). This is important for it represented a conscious attempt to distance himself from the English bourgeoisie and points to the interplay between nation and class that formed a centrally important part of his writing. 
Although he left school at 16 and moved in very different social circles to Williams, Ian Woosnam's accent was one characterized by the distinctive burr of the border country - in his case a brogue representative of the agricultural landscape of Shropshire, England. This area has been identified as an interesting one for tourism development and in conjunction with the neighbouring counties of Herefordshire (England) and Powys (Wales) was a space that 'had a special identity as an ancient borderland, neither truly English nor truly Welsh' (Saxena and Ilbery 2008: 249). Kneafsey (2000) has highlighted the importance of understanding the particularities of historical configurations and newer social relations within any specific locale. Williams (1979b/2003) reflected on growing up in his own border country where 'there was a curious sense in which we could speak of both Welsh and English as foreigners, as "not us"' (50).

At one level Woosnam and Williams may seem like a strange coupling but what they share is the experience of growing up in a border country with its complex interplay of a range of identities. Williams (1971/2003: 3) once noted that 'I used to think that born into a Border country at once physical, economic, and cultural, my own relationship to the idea of Wales was especially problematic' but would also reflect upon the fact that others from different parts of the country explored some similar tensions in making sense of Wales. At the heart of his work was the concept of 'structure of feeling' which points to both the objectivity of 'structure' with the more elusive notion of 'feeling' (see Williams 1973). Eldridge and Eldridge (1994) have noted the similarities of this to the sociological imagination of C. Wright Mills (1959) and point to the interconnective approach adopted by Williams and applied to all of his work. Whilst Williams reflected 
upon his own formative experiences in much of his academic writing it was in his works of fiction, such as Border Country (Williams 1960), that we really begin to see Wales in a wider sense. Each individual has her/his own unique relationship with their nation although in sport and tourism certain narratives come to the fore and others are marginalized. In moving on to the case-study that forms the focus of this paper I now look specifically at the role of Ian Woosnam.

\section{Ian Woosnam's Wales}

The homepage of the Ryder Cup Wales website featured a picture of Woosnam and the words 'Wales is a small country with big golfing ambition' (Ryder Cup Wales 2010). Woosnam is featured on the front covers of both the 'Golf as it should be' document (Visit Wales 2007) and the 'Services to Clubs Guide' (Ryder Cup Wales 2010 Ltd.) where he is also pictured on pages 3 and 20. His picture appears on three other occasions in the 'Golf as it should be' guide where an additional two-page feature article focuses on 'Ian Woosnam's Wales' (Visit Wales 2007, 8-9). His is the only image of a recognizable figure within any of the documentation hereby reflecting both his exalted status and the lack of any other recognizable individual in Welsh golf. What this means is that in some ways Woosnam becomes a reflection of Wales and Wales in turn becomes a reflection of him.

Miller, Lawrence, McKay and Rowe (2001: 31) note how 'the sporting body bears triumphant national mythologies in a double way, extending the body to encompass the nation and compressing it to obscure the social divisions that threaten national unity'. A short and squat figure with powerful arms, a legacy of his childhood growing up on a 
farm, the golfer fits the role of the little guy in a narrative that has some resonance for a small nation that has often struggled to be identified in the shadow of a larger, dominant neighbour. Whilst the guide states that 'Ian Woosnam wasn't quite born in a Welsh bunker' (Visit Wales 2007: 8) it does not of course note that Woosnam was actually born in England. For in sport, tourism and countless other broader social and political spheres, Wales and the essentialised construction of Welshness is often largely defined against not being England and English (see for example, Bowie 1993; Johnes 2005; Pitchford 1995).

Woosnam refers to the Welsh family background of both of his parents in his autobiography (Woosnam 2002). In the 'Golf as it should be' guide he states how annoyed he got when people used to ask him which part of England Wales was in. Healso notes how he used to try and promote the quality of Welsh golf courses overseas 'but it was pretty much a lonely job' (Visit Wales 2007: 8). Here then we see how this one individual assumed a very important role in promoting his nation as he was in many ways the sole standard bearer for the country. This is outlined in his autobiography by the following extract:

By 1987, the significance of my Welshness seemed somehow index-linked to my success in the game. The more I won, the more people seemed to know where I came from and, consequently, the more proud I felt to call myself a Welshman.

(Woosnam 2002: 113)

For many within the international golf community he became the Welsh and the Welsh in turn were collapsed to be Ian Woosnam evidencing the ways in which the sporting body 'bears triumphant national mythologies' (Miller et al. 2001: 31). The great challenge in 
promoting Wales as a distinct and identifiable entity to potential tourists has been highlighted elsewhere (e.g. Pitchford 1995; Pritchard and Morgan 1996). This challenge was perhaps accentuated in attempting to capitalize on the hosting of the 2010 Ryder Cup given that in trying to develop golf tourism Wales would be competing against neighbouring nations that had a far more established position in this field.

\section{Golf as it should be: Challenging dominant ideologies}

Woosnam's visibility in relation to the 'Golf as it should be' campaign is also important for he provides a physical reference point beyond the rhetoric and 'brand-speak' of tourism marketing. The challenges faced in developing a presence in the competitive golf tourism market are evidenced in Woosnam's observation that Scotland and Ireland 'had a hundred years start on us so we had a lot of catching up to do' (Visit Wales 2007: 8). The 'Golf as it should be' strategy aimed to position Wales as a challenger brand. Pride (2004: 159) notes how when it comes to branding the most difficult task facing any destination 'is the quest for true differentiation'. Wales is (re)positioned as distinct from its competitors by positioning it as 'the antidote to the golfing scene in the competitor countries' (Pride 2004: 164). This was a clever marketing campaign aiming to highlight a differentiation but the challenge of basing this around an event that is by its very nature a very exclusive one (see Morrow and Wheatley 2003) presents an interesting paradox. The image that is promoted is of a golfing destination far removed from the 'corporateness of England' (in Pride 2004: 165) yet at the same time key stakeholders need to use the sport as a means of attracting corporate sponsors and inward investment.

As a visible image in both Ryder Cup Wales and Visit Wales documentation, 
Woosnam represents an ever-present and symbolically important figure of the Welsh golfing landscape. A farmer's son who spent his early years as a professional golfer struggling to make a living on the tour, Woosnam lived in a camper van and travelled from tournament to tournament surviving on a diet comprising largely of baked beans. His avowed fondness for a beer and a cigarette (Woosnam 2002) lead to the 'Boozy Wossie' tag but this also served to position him as less aloof and more approachable than some of his peers. At a time when golfers increasingly appeared more distant and dislocated from fans as considerable prize money reshaped the game (Sounes 2004) Woosnam's popularity was shaped in part by his perceived 'ordinariness' even though he also reaped the huge financial rewards now available. The importance of his national identity cannot be over-stated here in attempting to give Wales a presence in an area where they have long-struggled to present a distinct and identifiable image. The challenges of promoting Wales and a Welsh identity in the USA (see Pritchard and Morgan 1996), and the wider problems in (re)positioning this against other nearby nations in the golf tourism market place are evidenced by the following extract from Woosnam's autobiography:

“So, Woosie, you're from Wales?" an American journalist had asked during a press conference earlier in the year.

“That's right" I replied.

"So what part of Scotland is that?"

The room erupted in laughter, but the guy had been entirely serious! I shook my head, and took another question.

(Woosnam 2002: 113) 
Whereas Woosnam won the US Masters title in 1991, and was once ranked the Number One golfer in the world, for much of the first decade of the new millennium no Welsh player appeared in the top 100 of world golf. No Welshman made the 2010 European Ryder Cup team and so the first time in the history of the event here was no golfer from the 'host' nation present in the home team.

Apart from Woosnam, Philip Price (in 2002) was the only other Welsh player to feature as part of a European team at the time the event was staged in Wales (although Jamie Donaldson was to play a key role for Team Europe in 2014). This represents a marked contrast to Scotland, Ireland and England who have each contributed many more players to Team Europe. Northern Ireland has also been much more visible within recent years with two of its golfers winning some of the major golf tournaments. Outside of this historic core, Spain has been represented in European teams by many more golfers in this same period and after the 2010 event Sweden and Italy had also now contributed more golfers to Team Europe than Wales.

As a small man, Woosnam also represented a perfect fit for a nation constantly battling against the odds and struggling to (re)assert itself against bigger opponents. The historian Gwyn A. Williams (1985) suggested that Wales is an 'artifact' made and remade over time, and usually framed within a British context. Whilst many are comfortable with this dual identity, it is also important to look at an additional layer and the place of a European identity within this configuration. Woosnam's importance, I argue here, was to incorporate Wales within a European context where he ensured that the Welsh would be a recognizable part of this broader collective and provided a physical 
reference point to draw upon.

The paucity of elite golfers from Wales ensured that Woosnam would (almost by default) have to be the focal point of any promotional literature where a recognizable face was needed. This makes his a somewhat unique role in recent Ryder Cup promotions for he became the identifiable symbol of the country. Other Ryder Cup matches staged outside of England had more reference points to contribute to the framing of local/national narratives but ahead of the 2010 event Woosnam stood alone as 'the Welshman'. In making sense of his role, and employing the self-definition of Raymond Williams, I suggest that Woosnam is best viewed as a Welsh European. Such a term points to the layered national and supranational identities and his long-term role as the significant figure in making Wales a visible part of (Team) Europe in golf.

\section{A Welsh European}

Suddenly England, bourgeois England wasn't my point of reference any more. I was a Welsh European, and both levels felt different.

(Williams 1979a/2003: 136)

Osmond (2001: 123) noted how people living in Wales can participate in a variety of identities noting that 'they can be Welsh, British, European ... [M]ore often than not they combine these attachments in varying degrees of intensity'. He also notes how for the Welsh the notion of being European is perhaps easier than it is for the English because they are used to dealing with multiple identities. Wales found itself wiped off the map of Europe in 2004 when the front cover of the Euorostat Yearbook had somehow sunk the country into the Irish Sea! The Western Mail (self styled papur cenedlaethol Cymru, the national newspaper of Wales) printed a dot-to-dot map of the country for the European Union to cut out and keep. 
Williams grew up in a small Welsh village six miles from the English border where a very strong local sense of identity meant that villagers would refer to both the Welsh and the English as 'not us' (Williams 1979b/2003: 50). For Woosnam, all opportunities to play golf had to fit around farming commitments (Woosnam 2002). His border country dictated that he learned the game of golf on a course where fifteen of the holes are in Wales but players cross into England to play three other holes. The significance of crossing the border between Wales and England was one that Williams reflected upon throughout his career and was an important journey in shaping his analyses of many other aspects of culture.

Anderson's (1983) descriptor of nations as 'imagined communities' has been used by a range of scholars including those interested in tourism and sport. Whilst the imagined community of millions has been described as being more real when conceived as a team of eleven named individuals playing football (Hobsbawm 1990), so then I would suggest the idea of Europe is perhaps best imagined through the image of twelve named individuals representing the continent in a biennial golf match. In other sports, such as football, Europe has long served as a distant and far away 'other' for many British supporters. Teams have long talked of 'getting into Europe' (Williams and Wagg 1991) and national stereotypes form a central part of sports reporting where sport is situated within and around wider social and political discourse and there is evidence of both hostility and pro-European affirmations (Blain, Boyle and O’Donnell 1993; Steen 2015). Steen's (2015) recent work on the Ryder Cup noted the focus on 'continental collectivity' within the British media reporting of the event. 
While it may be promoted and oftentimes celebrated as a symbol of a united Europe, the Ryder Cup team has always been one with an established British and Irish core. Outside of the five nations who contributed to the Great Britain and Ireland configuration, only seven other nations have had representatives in the European team to date. On average a European Ryder Cup team will consist of 7-8 players from Great Britain and Ireland and only Spain and Sweden have really positioned themselves as part of the core of Team Europe. The Europe represented in a Ryder Cup team then is still very much a Western European one and is based upon a very narrow geographical core. It was his engagement with the work of other European intellectuals that Williams reflected upon noting that 'I am now necessarily European' and that ' $[\mathrm{t}] \mathrm{he}$ people to the left and on the left of the French and Italian communist parties, the German and Scandinavian comrades $[\ldots]$ are my kind of people; the people I come from and belong to' (Williams 1979a/2003: 136). His self-definition as a 'Welsh European' emphasizes the importance of social class, the challenging of a dominant hegemony, and the interplay of nation and class which have been identified as central to the case-study discussed in this paper. In trying to capture the significance of one individual, at a particular time, I have attempted to tease out elements of the relationship between biography and society as presented within tourism promotion discourse.

\section{Concluding Remarks}

This work has attempted to explore the role of an individual within wider national tourism discourse around the staging of a mega-event. It has also highlighted the role of the stateless nation of Wales as host of the event. As the most (and perhaps only?) 
recognizable figure in Welsh golf, Woosnam played an important role in promoting the 2010 Ryder Cup and ensured that the event had some recognizable links to Wales beyond just the location of the match itself. His visibility and recognition within the international golfing industry both collapsed and extended the sporting body to encapsulate the nation through this one figure. The role of an individual, and having his biography positioned within and around wider social and cultural developments, points to continuity and change in better understanding the ways in which Wales and Europe are (re)imagined within the particular context of the case-study discussed here.

Hall (1996: 4) noted that it is precisely because identities are constructed within and not outside of discourse that 'we need to understand them as produced in specific historical and institutional sites'. The positioning of Woosnam as a Welsh European speaks to the continuity and change of identities. This one figure is extended (as Wales) and then further extended (Wales as part of Europe) in the sporting discourse to represent a particular place. His personal biography, on some levels, fits a narrative that attempts to position Wales and Welsh golf as something distinct from the 'corporateness' of England. In engaging with the work of Raymond Williams it is important to acknowledge that he was a critic of global capitalism. The discourse used in 'branding' Wales as a tourist destination may have been far removed from his own understanding and feeling for that place. What we do know was that Williams did enjoy televised sport and once noted that he would keep his television set for it alone. For sports fans in the UK, live coverage of the 2010 Ryder Cup was only available to those who had paid for a subscription to Sky television. This is a subject that Williams would surely also have had some strong opinions on. 
Yet although it is clear that Woosnam provides an important site for the incorporation of Wales into European golfing narratives it is important not to position this alongside an essentialised construction of Welshness and a particular imagined identity. Woosnam was born over the border in England and spent much of his adult life in Jersey where the advantages of paying lower taxes were clearly influential (Woosnam 2002). Although born in Wales, Raymond Williams lived in England for most of his adult life and is best known for his scholarship on English literature and culture. His selfdefinition as a Welsh European reflected both an increased national consciousness and awareness, alongside a conscientious rejection of the English bourgeoisie. I have applied this descriptor to Woosnam here as a means of highlighting the golfer's significant role as a marker of Wales where as a playing member, and later captain, of Team Europe he ensured that Wales were represented in Ryder Cup matches and that his small nation was a visible part of Europe within golfing narratives at least. He was the first Welsh player to be part of Team Europe and for the foreseeable future will be the only golfer from Wales to have assumed the captaincy of this collective.

Raymond Williams is celebrated for his academic contribution but his work as a novelist is often overlooked. Here, in novels such as Border Country, rich descriptive accounts of the landscape and reflections on the importance of place clearly situate the author and indicates a sense of topophilia (love of place) in evidencing the strong attachment to a particular locale (Williams 1960). This was something that was also very much evident in Woosnam's (2002) autobiography and provided part of the discourse framing Woosnam's role as an ambassador of Welsh golf and in the words he contributed to the various tourism texts ahead of the 2010 Ryder Cup. Pritchard and Morgan (2001: 
177) pointed to the ways in which space, place and landscape 'are in constant flux' and noted how the meaning of Wales as a tourism space was shifting. In more recent years we have seen this shift ever more and the development of Wales as a tourist destination has continued apace.

Whilst he did not play any part in a thrilling victory for Team Europe in 2010, it was in many ways still Ian Woosnam's Ryder Cup. The most celebrated figure in Welsh golf became something of a reassuring identifier to the competition and ensured that the Welsh could be part of this wider European collective. In the rain-soaked hills of south Wales he provided a comforting and continuous link to make Europe the home team. For four days many of the spectators from the host nation themselves became 'Welsh Europeans' and cheered on fellow Europeans.. .

Beyond a strong English core at the heart of the 2010 Ryder Cup team, five other nationalities were represented in Team Europe. There is some evidence of an emerging Europeanisation of the Ryder Cup with two future events scheduled to take place in continental Europe, but 37 years on from the creation of a European team only twelve different nationalities have represented the collective to date. In a referendum on whether Britain should remain a part of the European Union (on June 23, 2016) the British electorate voted to leave. This so-called 'Brexit' will dramatically reshape the role of Britain within Europe. Whilst international sport is largely about politics with a small 'p', it will be interesting to observe how this supranational collective and a pan-European identity are portrayed in the media coverage of upcoming Ryder Cup matches. The Ryder Cup is perhaps the only sporting event where the European flag is waved by 
spectators although the various national flags of the team members also feature prominently.

Sharratt (2001: 307) noted that although Williams may be claimed as a Welsh novelist "his own emphasis on a shared "culture" (in that larger sense) took him conceptually and imaginatively beyond the familiar but problematic boundaries of "nation" or "state" and their accompanying assumptions'. In considering the role of Ian Woosnam as a Welsh European this study has explored the ways in which an individual represents a nation within tourism discourse to provide a physical reference point upon which to position the host nation of a mega-event within a supranational collective.

\section{References}

Aaron J and Williams C (2005) (eds) Postcolonial Wales. Cardiff: University of Wales Press.

Anderson B (1983) Imagined Communities. London: Verso.

Bale J (2003) Sports Geography. London: Routledge.

Blain N, Boyle R and O’Donnell H (1993) Sport and National Identity in the European Media. Leicester: Leicester University Press.

Bowie F (1993) Wales from within: conflicting interpretations of Welsh identity. In MacDonald S (ed) Inside European Identities, Oxford: Berg.

Briassoulis H (2007) Golf-centered development in coastal Mediterranean Europe: a soft sustainability test. Journal of Sustainable Tourism 15: 441-462.

Chaney P (2015) Exploring political parties' manifesto discourse on tourism: analysis of Scottish, Welsh and Northern Irish elections 1998-2011. Annals of Tourism Research 50:113-127.

Concannon D (2004) The Ryder Cup (revised edn.). London: Aurum Press.

Edensor T (2002) National Identity, Popular Culture and Everyday Life. Oxford: Berg. 
Eldridge J and Eldridge L (1994) Raymond Williams: Making Connections. London: Routledge.

Frew E and White L (2011) (eds) Tourism and National Identities: An International Perspective. London: Routledge.

Gelan A (2003) Local economic impacts: The British Open. Annals of Tourism Research 30: 406-425.

Gibson H (1998) Sport tourism: A critical analysis of research. Sport Management Review 1: 45-76.

Gibson H and Pennington-Grey L (2005) Insights from role theory: Understanding golf tourism. European Sport Management Quarterly 5: 443-468.

Hall S (1996) Who needs identity? In Hall S and Du Gay P (eds) Questions of Cultural Identity, London: Sage.

Harris J (2015) Keeping up with the Joneses. Hosting mega-events as a regenerative strategy in nation imaging, imagining and branding. Local Economy 30: 961-974

Hobsbawm E (1990) Nations and Nationalism since 1780. Cambridge: Cambridge University Press.

Hubbert J (2015) Back to the future: The politics of culture at the Shanghai expo. International Journal of Cultural Studies (Online first).

Hudson S and Hudson L (2010) Golf Tourism. Oxford: Goodfellow Publishers.

Hutchinson J, Lai F and Wang Y (2009) Understanding the relationship of quality, value, equity, satisfaction, and behavioral intentions among golf travelers. Tourism Management 30: 298-308.

Inglis F (1995) Raymond Williams. London: Routledge.

Johnes M (2005) A History of Sport in Wales. Cardiff: University of Wales Press.

Jones C (2001) Mega-events and host-region impacts: Determining the true worth of the 1999 Rugby World Cup. International Journal of Tourism Research 3: 41-251.

Jones RM (1992) Beyond identity? The reconstruction of the Welsh. Journal of British Studies 31: 330-357.

Kim S, Kim J and Ritchie B (2008) Segmenting overseas golf tourists by the concept of specialization. Journal of Travel \& Tourism Marketing 25: 199-217.

Kneafsey M (2000) Tourism, place identities and social relations in the European rural 
periphery. European Urban and Regional Studies 7: 35-50.

Laclau E and Mouffe C (1985) Hegemony and Socialist Strategy. London: Verso.

Lim C and Patterson I (2008) Sport tourism on the islands: The impact of an international mega golf event. Journal of Sport \& Tourism 13: 115-133.

McGuigan J (2014) Introduction: Raymond Williams's contribution to cultural studies and sociology. In J. McGuigan (ed) Raymond Williams on Culture \& Society: Essential Writings, London: Sage.

Miller T, Lawrence G, McKay J and Rowe D (2003) Globalization and Sport. London: Sage.

Mills CW (1959) The Sociological Imagination. New York: Oxford University Press.

Morgan N and Pritchard A (2005) Promoting niche tourism destination brands. Journal of Promotion Management 12: 17-33.

Morrow S and Wheatley G (2003) The Ryder Cup 2014: Golf's homecoming? Scottish Affairs 43: 108-126

Osmond J (2001) Welsh politics in the new millennium. In Morley D and Robins K (eds) British Cultural Studies, Oxford: Oxford University Press.

Paasi A (2001) Europe as a social process and discourse: Considerations of place, boundaries and identity. European Urban and Regional Studies 8: 7-28.

Petrick J (2002) An examination of the construct of perceived value for the prediction of golf travelers' intention to revisit. Journal of Travel Research 41: 38-45.

Pitchford S (1995) Ethnic tourism and nationalism in Wales. Annals of Tourism Research 22: 33-52.

Pride R (2004) A challenger brand: Wales, golf as it should be. In Morgan N, Pritchard A and Pride R (eds) Destination Branding: Creating the Unique Destination Proposition ( $2^{\text {nd }}$ ed), Oxford: Elsevier.

Pritchard A and Morgan N (1996) Selling the Celtic arc to the USA: A comparative analysis of the destination brochure images used in the marketing of Ireland, Scotland and Wales. Journal of Vacation Marketing 2: 346-365.

Pritchard A and Morgan N (2001) Culture, identity and tourism representation: marketing Cymru or Wales? Tourism Management 22: 167-179.

Rahman M and Lockwood S (2011) How to 'use your Olympian': The paradox of 
athletic authenticity and commercialization in the contemporary Olympic Games. Sociology 45: 815-829.

Ritchie JRB (1984) Assessing the impact of hallmark events: Conceptual and research issues. Journal of Travel Research 23: 2-11.

Ryder Cup Wales (2008) Your route to the 2010 Ryder Cup.

http://www.rydercupwales2010.com/en/fe/page.asp?n1=3 (Accessed August 22, 2008)

Ryder Cup Wales (2010) About us.

http://www.rydercupwales2010.com/en/fe/page.asp?n1=2 (Accessed September 17, 2010)

Ryder Cup Wales 2010 Ltd (2008) Services to Clubs. Cardiff: Ryder Cup Wales 2010 Ltd.

Salazar-Sutil N (2008) Maradona Inc: Performance politics off the pitch. International Journal of Cultural Studies 11: 441-458.

Saxena G and Ilbery B (2008) Integrated rural tourism: A border case study. Annals of Tourism Research 35: 233-254.

Sharratt B (2001) Writing Britains. In Morley D and Robins K (eds) British Cultural Studies, Oxford: Oxford University Press.

Silverman D (2001) Interpreting Qualitative Research (2 ${ }^{\text {nd }}$ ed.). London: Sage.

Smith A and Porter D (2004) (eds) Sport and National Identity in the Post-war World. London: Routledge.

Smith D (2008) Raymond Williams: A Warrior's Tale. Cardigan: Parthian.

Sounes H (2004) The Wicked Game. New York: HarperCollins.

Stafford I (2006) Easy Ryder: Europe's magnificent $K$ club triumph - Three in a row! Edinburgh: Mainstream.

Steen R (2015) Uneasy Ryder: The Ryder Cup, anti-Americanism and the 'Yoo-rop' phenomenon. Sport in Society 18: 347-363.

Turner G (1990) British Cultural Studies. Boston, MA: Unwin Hyman.

Visit Wales (2007) Wales Golf Guide: golf as it should be. Cardiff: Welsh Assembly Government.

Weed M (2009) Progress in sport tourism research? A meta-review and exploration of 
futures. Tourism Management 30: 615-628.

Whannel G (2008) Culture, Politics and Sport. London: Routledge.

Williams D (2003) (Ed) Who Speaks for Wales? Nation, Culture, Identity: Raymond Williams. Cardiff: University of Wales Press.

Williams GA (1985) When was Wales? London: Penguin.

Williams J and Wagg, S (1991) (Eds) British Football and Social Change: Getting into Europe. London: Leicester University Press.

Williams R (1958) Culture and Society 1780-1950. London: Chatto \& Windus.

Williams R (1960) Border Country. London: Chatto \& Windus.

Williams R (1961) The Long Revolution. London: Chatto \& Windus.

Williams R (1964) Second Generation. London: Chatto \& Windus.

Williams R (1971/2003) Who speaks for Wales? In Williams D (ed) Who Speaks for Wales? Nation, culture, identity: Raymond Williams. Cardiff: University of Wales Press.

Williams R (1973) The Country and the City. London: Chatto \& Windus.

Williams R (1976) Developments in the sociology of culture. Sociology 10: 497-506.

Williams R (1977) Marxism and Literature. Oxford: Oxford University Press.

Williams R (1979a/2003) The Welsh trilogy and the volunteers: Interview with New Left Review. In Williams D (ed) Who speaks for Wales? Nation, culture, identity: Raymond Williams, Cardiff: University of Wales Press.

Williams R (1979b/2003) Boyhood: Interview with New Left Review, in Williams D (ed) Who Speaks for Wales? Nation, culture, identity: Raymond Williams, Cardiff: University of Wales Press.

Williams R (1983) Towards 2000. London: Chatto \& Windus.

Woosnam I with E Griffiths (2002) Woosie: My autobiography. London: CollinsWillow. 